\title{
ジルコン中の微量鉛の定量分光分析法
}

\author{
森田清*
}

（昭和 35 年 4 月 26 日受理）

\section{A Spectrographic Determination of Lead in Zircon}

\author{
Kiyoshi MORITA*
}

(Government Industrial Research Institute, Nagoya)

The age of igneous rocks is being determined by analyzing lead content of zircon in them and at the same time by determining its $\alpha$ radioactivity. A spectrographic method of determining lead in zircon for the use in age determination is described. As the base and the internal standard silica and indium are used respectively with the excitation by D.C. arc. A JACO $3.4 \mathrm{~m}$ grating spectrograph is used, the line pairs selected are $\mathrm{Pb}$ (I) $2833.1 \AA$ and In (I) $2932.6 \AA$. This method is applicable to samples containing lead from 5 to $1,000 \mathrm{ppm}$ with an accuracy of about 6-10 per cent in error. The accuracy was lowered to 17 per cent when the amount was as low as $1 \mathrm{ppm}$.

This analytical method was applied to zircon obtained from biotite granite and granodiorite newly quarried near Nagoya and zircon samples from Korea, Formosa and Australia. Results of analysis are given.

\section{1. 緒言}

分光分析法によるジルコン中の鉛の定量については, Waring ${ }^{1)}$ が無水珠酸を基体としてビスマスを内標準と して検討を行なつている。 また Wabber ${ }^{2)}$ や Larsen ${ }^{3)}$ は花崗岩中のジルコンを分離して $\alpha$ 線強度を測定し, 鉛 の定量は Waring 法を参考とし, あるいは同法によつ て定量して地質年代の決定を試みている。このようにジ ルコンはその特性上新鮮な形で，かつ単結晶として取り だせることが年代決定のための鉱物とされる訳であり， 国内においてもジルコンによる年代決定の試みがなされ ようとしている。筆者は内標準としてインジウムを用い

* 名古屋工業技術試験所：名古屋市北区平手町 1-1

1) Waring, C.L. and Worthing, H.: AEC report TEI-216, (1952).

2) Webber, G.R., Hurley, P.H. and Fairbairm, H.W.: Am. J. Sci., 254, 574 583, (1956).

3) Larsen, E. S. Jr., Keevil, N. B., and Harrison, H.C.: Geol. Soc. America Bull., 63, 1045 1052, (1950).
てその定量法を再検討し，精度をジチゾン法による比色 分析と比較したところ，まずは満足すべき結果を得た。 ついで愛知県下の花崗岩および蛙目粘土中のジルコンに ついて鉛の定量を行なつたのでここに報告する。

\section{2. 実験方法亡考察}

標準試料としては無水珪酸を基体とし，これに硝酸鉛 溶液を浸透させ乾燥，低温で焼いたものを用いた。すな わ⿱ 求める鉛の含有量を保有せしめた試料によりまず分 析の可能性を検討し，ついで内標準を混合したものにつ いて検量線を作成した。つぎ実際の試料として花崗岩 および花崗閃緑岩中のジルコンについて鉛を定量し，あ わせてその他三三のジルコンについて鉛を定量した。

\section{(1) 装置および発光条件}

実験は JACO $3.4 \mathrm{~m}$ 名析格子分光器を用い, 発光条件 は後に述べる種々の予供実験の結果 Table 1 に示す条 件を用いてスペクトルを撮影した. 測光は JACO ミクロ フォトメーターにより $\mathrm{Pb}$ (I) $2833.1 \AA$ 期 (I) $2932.6 \AA$ の分析線対について行ない, 階段七クターを使用, 乾板 較正は. Seidel によつた。 
Table 1. Experimental conditions for the analysis of lead in zircon.

\section{Spectrograph:}

JACO $3.4 \mathrm{~m}$ Plane Grating Spectrograph

Electrode:

Regular Electrode of Nippon Carbon Co.

Illuminating system:

Intermediate Imaging

Grating angle:

9. $40^{\circ}$ 2nd Order

Slit width:

$0.050 \mathrm{~mm}$ for $1 \sim 100 \mathrm{ppm} \mathrm{Pb}$

$0.020 \mathrm{~mm}$ for $50 \sim 1,000 \mathrm{ppm} \mathrm{Pb}$

Current:

D.C. $7.5 \mathrm{~A}$ for $1 \sim 100 \mathrm{ppm} \mathrm{Pb}$

D.C. $9.5 \mathrm{~A}$ for $50 \sim 1,000 \mathrm{ppm} \mathrm{Pb}$

Analytical gap: $3 \mathrm{~mm}$

Exposure time:

$30 \mathrm{sec}$. for $1 \sim 100 \mathrm{ppm} \mathrm{Pb}$

40 sec. for $50 \sim 1,000 \mathrm{ppm} \mathrm{Pb}$

Photographic process:

Fuji Spectroscopic Process Plate Development, 4 min. at $20^{\circ} \mathrm{C}$ in $\mathrm{FD}-31$

Fixing, 5 min. at $20^{\circ} \mathrm{C}$ in $\mathrm{FF}-\mathrm{H}_{4}$

Densitometry:

JACO Recording Microphotometer J.A. 2310

Emission:

Iron arc. Step Sector. Each Plate was Calibrated by the Seidel Method.

\section{(2) 標準試料}

基体として使用する $\mathrm{SiO}_{2}$ については鉛の含有量放少 くとも spec. pure 程度に少ないものでなければならな い.このため市販の最も純度の高い $\mathrm{SiO}_{2}$ について数回 酸による脱鉛操作をくり返した、酸洼熱塩酸を用いたが 特級塩酸といえども微量の鉛学有するので脱鉛操作は 2 3回で止めて, 分光分析による定性を行ない, 分光学的 に純なものを確認した上で標準基体とした.ついでジョ ソソン・マッセイ社の spec. pure な $\mathrm{PbO}$ を硝酸に溶 解，硝酸鉛の標準溶液总調製し，その一定量をこの基体 に加え白金ルツボ中で徐々に乾燥したのち電気炉中で低 温で加熱し硝酸を追い出し鉛含有標準基体とした。調製 した標準基体は $1 \mathrm{~g} の \mathrm{SiO}_{2}$ に対し $\mathrm{Pb}$ とて $0.69 \mathrm{mg}$, $0.069 \mathrm{mg}, 0.0069 \mathrm{mg}$ 念有するものであつた. この 標準基体にさらに $\mathrm{SiO}_{2}$ を加え $\mathrm{Pb}$ として 1 1,000 ppm の各段階に相当する試料を調製した．ここに問題となる のは機械的な混和作業であるが従来行なわれている乳鉢 による混和についで篩による操作の繰り返しは，数回の 実験の結果時として不充分なことがあるのと，また非常 な時間と労苦とを必要とするので, ポットミル回転装置 を改良した混合装置を試作し平均 5 時間以上の機械かく
ほえと回転による試料の混和を行なつた，実験の結果任 甚だ満足すべきものであつたので，今回の実験の試料混 和はすべてこの方法によつた。

\section{（3）内標準と分析線対}

内標準と乙て鉛と分光学的に近似方ると思わ机る元素 として考えられるものに $\mathrm{Bi}, \mathrm{In}, \mathrm{Ag}, \mathrm{Cd}$ 等がある. Ahrens ${ }^{4)}$ によれば In が比較的よい傾向军示正ことが 知台れている。また $\mathrm{Bi}$ 注 Waring が AEC の并究に ふいて用いているので，筆者はInをとり岁げその可能 性觉裕封した。

鉛のスペクトル線として低濃度まで検出可能なるのは 2833.1 1 の久であるので，このスペクトル線に対応す るInのスペクトル線として $2710.3 \AA ， 2713.1 \AA$, $2753.9 \AA, 2836.9 \AA ̊ 丿, 2932.6 \AA, 2957.0 \AA$ について検 討乙た。

忘た内禋準としての In 怡鉛の試料調製の要領により 行なつた、すなわち spec. pureな金属インジウム足塩酸 に溶解，基体の $\mathrm{SiO}$ 亿浸透さ㥀燥， $400^{\circ} \mathrm{C}$ 以下で電 気炉中で燒き 5 時閒以上回転混和した，つぎに In を含 有する $\mathrm{SiO}_{2}$ 学鉛の標準試料に一定量加えた試料を発光 さ朖内標準としての適当な含有量を決定した，実験に供 した In の添加量は

$\mathrm{Pb}$ 1 100 ppm の試料に対しては 0.06\%

$\mathrm{Pb} \quad 50 \sim 1000 \mathrm{ppm}$ の試料に対しては $0.19 \%$

它含有させることが選定点の関係から考慮して適当な量 であつた。客たInのスペクトル線の中，上記の配合にお いて鮮明学黑化度宗すものは In (I) $2932.6 \AA$ であつ たから分析線詨として Pb (I) $2833.1 \AA$ In (I) $2932.6 \AA$ を使用した。

\section{（4）電流強度の影響}

鉛，インジウム共に融点の低い元素であるため電流強 度の影響も大きい。一方 JACO の発光装置では D.C. アークとしては $6 \mathrm{~A}$ 以下では放電しないので $6 \mathrm{~A}$ 以上 の電流強度において検討定行なつた。 その結果 $7 \mathrm{~A}$ 以下 では $\mathrm{Pb}$ の黑化度は小となり，また放電が不安定であ る. また放電初期の D.C. アークが安定せず試料の飛散 它生じや索い。10 A 以上では放電の安定化は早いがバ ックグラウンドが強く測光上の誤差を大きくする. 以上 の実験結果より 7.5〜9.5 A 閒が適当であると考えられ る.

\section{（5）電極の形状と線強度}

下部電極の形状として Fig. 1 に示す $\mathrm{A}, \mathrm{B}, \mathrm{C}$ の最

4) Ahrens, L. H.; "Spectrochemical Analysis" p. 158 (1950). 
も普通の型のものについて検討した．この場合上部電極 は一定の円錐形に先端を細くしたものとし，下部電極孔 はその深さを $3 \mathrm{~mm}$ とした，A の場合は B，C に比し て温度上昇がおそいので放電が不安定となり, 試料の溶 融が放電初期に抢いて均一化されず, 測定值のバラッキ が比較的大きい。ただし電極を細くした場合この影響を ある程度除くことができた. B の場合試料の溶融が早く 初期において電流が安定化する. Cの場合法電極中央先 端で放電が行われるため初期から放電が安定である。乙 かし試料は表面の久が溶融するため放電終了時において も試料全体が溶融しない場合がある. そこで電極孔につ めた試料の中央部に針で穴をあけた場合を試みたところ 比較的よい結果が得られた。このように実験を重ねた結 果 1 100 ppm Pb のものではB の型觉， $50 \sim 1000 \mathrm{ppm}$ $\mathrm{Pb}$ では $\mathrm{A}$ の型で径を $5 \mathrm{~mm}$ とし, いずれも試料中央 部に針で穴をあけて用いた。

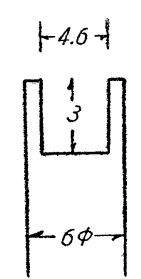

A

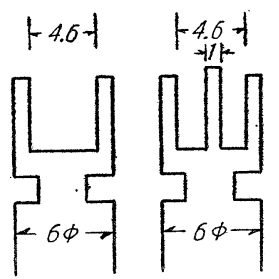

$\mathrm{C}$
Fig. 1: Forms of electrodes.

\section{（6） 添加物の影艟}

鉛の定量にはWaringがアルカリふれ囲気で好結果を 得ているが，本実験でもこのことを実証した。すなわち $\mathrm{Na}_{2} \mathrm{CO}_{3}, \mathrm{AgCl}$, 黑鉛, $\mathrm{BaF}_{2}+\mathrm{C}$ のそれぞれを添加し た場合を比較したが $\mathrm{Na}_{2} \mathrm{CO}_{3}$ 以外は強度は多少増大す るが同時にバックグラウンドも強くなり適当ではなかつ た. そこで $\mathrm{Na}_{2} \mathrm{CO}_{3}$ について混合割合を重量比 $1: 0.5$, $1: 1,1: 2,1: 3$ の場合を検討したが顕著な差異は認めら れなかつた、ただ前記のように放電が安定するのとバッ クグラウンドがきれいになるので，その混合比を $1: 1$ と して用いた. Fig. 2 および Fig. 3 はこの結果を示す.

\section{(7) 露出時間の検討}

乾板移動法を行ない検討した. 試料は $50,500 \mathrm{ppm} の$ 2 試料を用い放電後 $10 \mathrm{sec}$. ごとの強度を測定した. $500 \mathrm{ppm}$ の場合では Fig. 4 に示すごとく $\mathrm{Pb}$, In 共 に $40 \mathrm{sec} . て ゙$ 消滅しその後はスペクトル線はでない. た $30 \mathrm{sec}$. までは同じ傾向を示すが $30 \sim 40 \mathrm{sec}$. 間で逆 になる. $50 \mathrm{ppm}$ では $20 \mathrm{sec}$. でスペクトル線がでない. すなわ蒸発しやすい両元素であるためと考えられるが

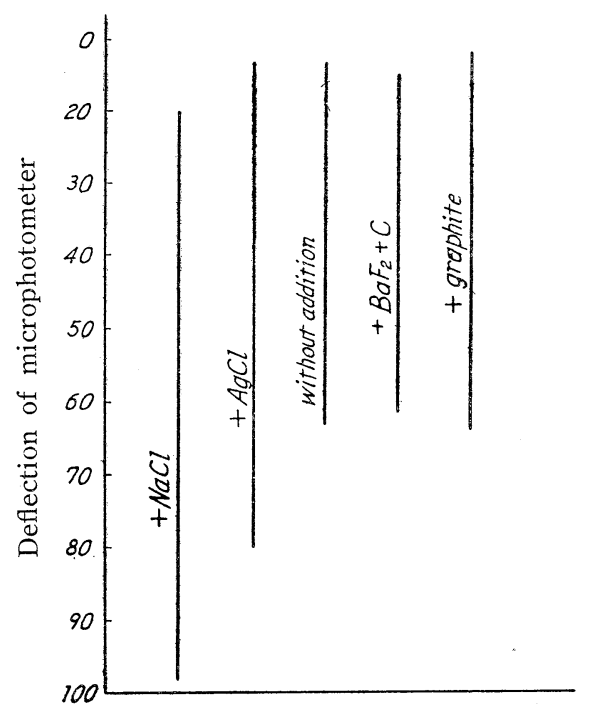

Fig. 2: Effect of added materials.

These results were obtained from the spectra of standard samples added with various substances.

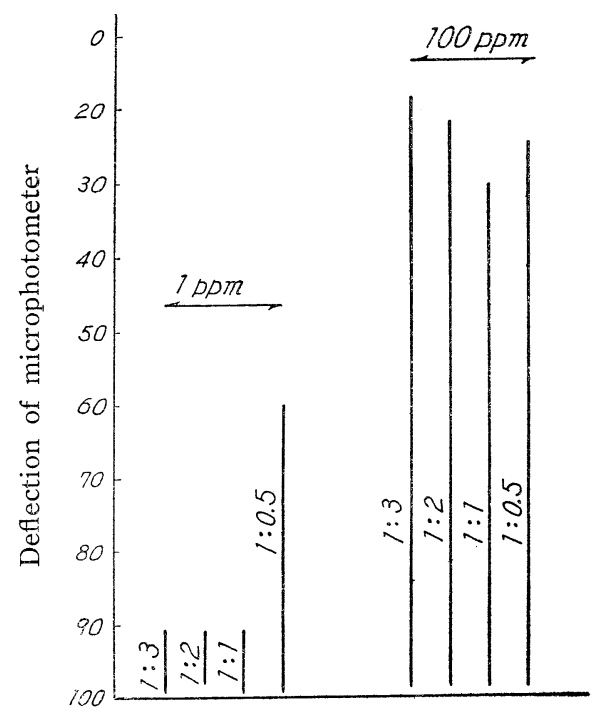

Fig. 3: Effect of $\mathrm{Na}_{2} \mathrm{CO}_{3}$.

These results were obtained from the spectra of standard samples added with various amounts of $\mathrm{Na}_{2} \mathrm{CO}_{3}$.

結局再現性の点からも両元素を完全に蒸発させるに必要 な時間を露出することがよいと考光られる. 従つて子備 放電は行わず

$$
\begin{array}{ll}
1 \sim 100 \mathrm{ppm} & 30 \mathrm{sec} . \\
50 \sim 1000 \mathrm{ppm} & 40 \mathrm{sec} .
\end{array}
$$


の露出をあたえることとした。また露出に関係するスリ ット幅は実験結果より 1〜100 ppm では $0.05 \mathrm{~mm}, 50$ $\sim 1000 \mathrm{ppm}$ では $0.020 \mathrm{~mm}$ とし, 電流強度はまた前 者では $7.5 \mathrm{~A}$, 後者は $9.5 \mathrm{~A}$ とし, 廻折格子の設置角 度 $9.40^{\circ}$ の 2nd order を撮影した。

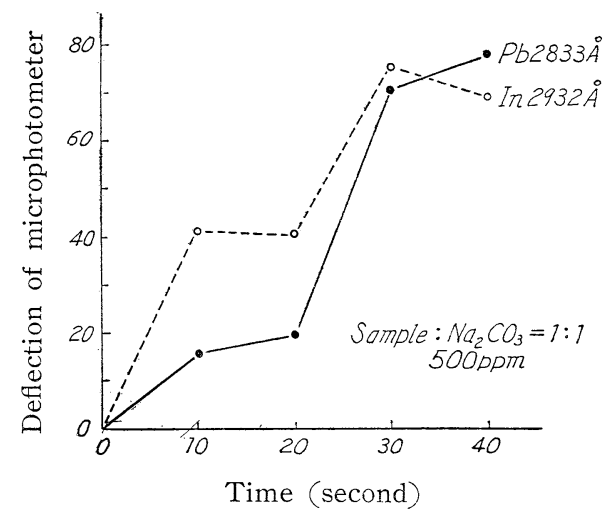

Fig. 4: Moving plate study of the spectral line intensity.

\section{(8) 䄃 量 線}

鉛の含有量として $1.1 \sim 1052 \mathrm{ppm}$ 間で 10 段階の試 料学調製し， $1 \sim 100 \mathrm{ppm}, 50 \sim 1000 \mathrm{ppm}$ の2 組に分 け，それぞれ 10 回ずつ発光して検量線を画いた. Fig. 5, Fig. 6 に示す.

\section{（9）標準試料中に存在する鉊量の推定}

標準試料あるいは試料調製に用いた試薬中には微量の

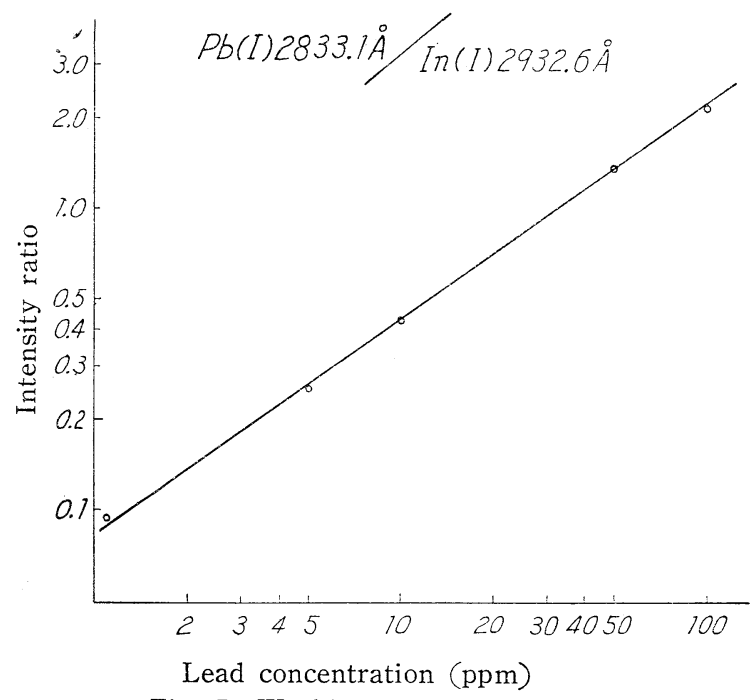

Fig. 5: Working curve for lead.
鉛が存在することが推定されるので，添加法51により作 図乙鉛の含有量を推定すると Fig. 7 のように約 $5 \mathrm{ppm}$ の存在が見込まれる。

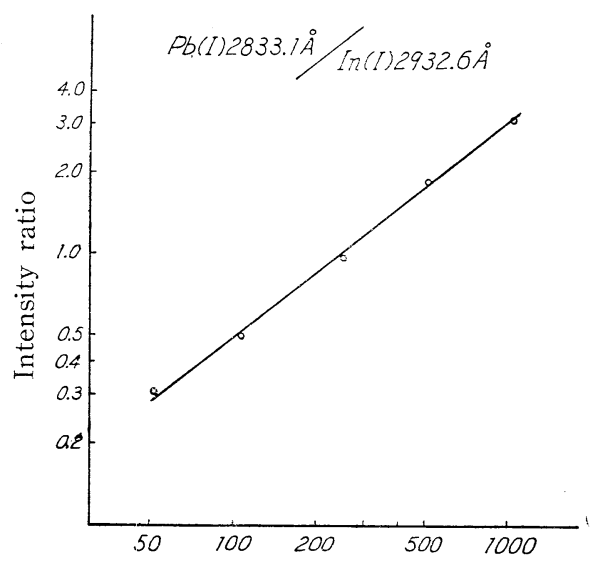

Lead concentration ( $\mathrm{ppm}$ )

Fig. 6: Working curve for lead.

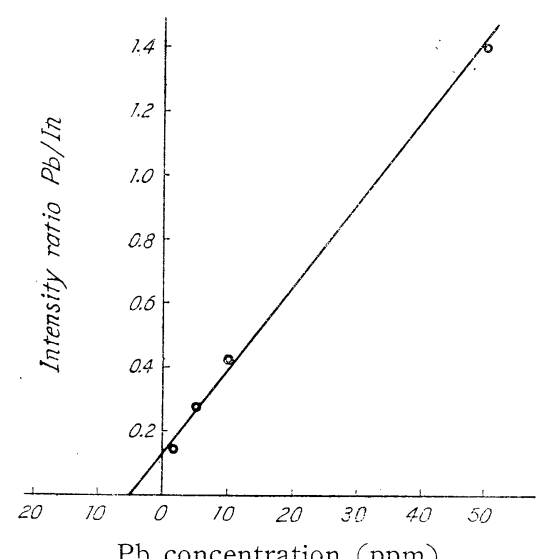

$\mathrm{Pb}$ concentration ( $\mathrm{ppm})$

Fig. 7: Presumption of residual lead by the addition method.

(10) 分析精度

Table 2 にそれぞれ 10 回ずつ発光した時の分析精度 を示し, 強度比の再現性を標準偏差として示した。 また 鉛の定量ではジチゾンによる比色定量が最も精度がよい とされているので，標準試料を分光分析した結果と所定 量の標準試料空 Sandell ${ }^{6)}$ の述べる方法にしたがつてジ チゾンにより比色分析した結果と文対比した. Table 3 にその結果を示声. 以上の結果より分光分析法による鉛 の定量は充分使用できるものといえる.

5) Ahrens, L. H.; “Spectrochemical Analysis' p. 135 (1950).

6) Sandell, E.B.; "Colorimetric Determination of Traces of Metals", p. 572, (1959). 
Table 2. Precision data.

\begin{tabular}{c|c|c|c|c|c|c|c|c}
\hline $\mathrm{Pb}$ added & $\begin{array}{c}1.1 \\
\mathrm{ppm})\end{array}$ & 5 & 10 & 50 & 105 & 246 & 509 & 1052 \\
\hline Intensity ratio & 0.100 & 0.234 & 0.40 & 1.29 & 2.34 & 1.03 & 1.67 & 2.90 \\
& 0.123 & 0.234 & 0.42 & 1.45 & 1.84 & 0.87 & 1.71 & 2.90 \\
& 0.098 & 0.259 & 0.37 & 1.16 & 2.05 & 1.08 & 1.81 & 2.96 \\
& 0.076 & 0.252 & 0.50 & 1.47 & 2.09 & 0.99 & 1.94 & 3.10 \\
& 0.074 & 0.259 & 0.47 & 1.30 & 1.90 & 0.85 & 1.93 & 3.40 \\
& 0.100 & 0.260 & 0.43 & 1.40 & 2.20 & 0.92 & 1.85 & 2.98 \\
& 0.118 & 0.240 & 0.44 & 1.50 & 2.16 & 0.98 & 1.80 & 3.40 \\
& 0.090 & 0.262 & 0.42 & 1.32 & 2.42 & 1.00 & 1.92 & 3.12 \\
& 0.095 & 0.270 & 0.43 & 1.47 & 2.12 & 1.02 & 1.96 & 2.98 \\
& 0.080 & 0.270 & 0.40 & 1.25 & 1.98 & 0.98 & 1.80 & 2.92 \\
\hline$\sqrt{\frac{\sum \nu^{2}}{n-1}}$ & $17.2 \%$ & $6.24 \%$ & $8.80 \%$ & $8.48 \%$ & $9.29 \%$ & $7.38 \%$ & $5.50 \%$ & $6.76 \%$ \\
\hline
\end{tabular}

Table 3. Precision data.

\begin{tabular}{c|c|c}
\hline $\mathrm{Pb}$ taken & $\begin{array}{c}\text { Pb found by the } \\
\text { spectro-chemical } \\
\text { method }\end{array}$ & $\begin{array}{c}\text { Pb found by the } \\
\text { colorimetric } \\
\text { method }\end{array}$ \\
\hline $10 \mathrm{ppm}$ & $11 \mathrm{ppm}$ & $10 \mathrm{ppm}$ \\
10 & 10 & 10 \\
10 & 11 & 10 \\
\hline 50 & 49 & 49 \\
50 & 50 & 49 \\
50 & 52 & 48 \\
50 & 47 & 50 \\
105 & 95 & 105 \\
105 & 115 & 108 \\
105 & 100 & 108 \\
105 & 98 & 107 \\
\hline
\end{tabular}

\section{3. ジルコン中の鉛の分析例}

本法の適用例としてジルコン中の鉛を定量した. まず 最初半定量的に鉛の含有量を知り, 内標準の添加量を定 め, 分光分析に供した. 定量值はとれぞれ 6 回ずつ発光 して得た平均值をとつた.これらの結果は Table 4 に示 すとおりである. 輸入された台湾, 朝鮮,オーストラリヤ のジルコンは碰力選鉱を行なつたものについて行ない, 試料 No. 1, No. 2 および No. 6 は比重選鉱, 重液選 鉱, 碰力選鉱を行ない, 最後に顕微鏡下でピンセットによ りジルコンを取りだしたものである。また No. 6 は蛙 目粘土採取の際, 廃砂としてすてられるものの中にジル コンが濃縮されているが，これらのジルコンについては 別の機会に報告する予定である.

Table 4. Lead contents of zircon.

\begin{tabular}{l|l|r|l}
\hline No. & \multicolumn{1}{|c|}{ Samples } & $\begin{array}{r}\text { Pb content } \\
(\mathrm{ppm})\end{array}$ & \multicolumn{1}{|c}{ Remark } \\
\hline $1^{* 1}$ & Fujioka Zircon & 81 & Found in Biotite Granite \\
$2^{* 2}$ & Akazu Zircon & 61 & Found in Granodiorite \\
3 & Zircon from Korea & 215 & \\
4 & Zircon from Formosa & 125 & \\
5 & Zircon from Australia & 81 & \\
$6 * 3$ & Fujioka Zircon (2) & 81 & Found in Gairome Clay of Fujii Mine \\
\hline
\end{tabular}

*1. 愛知県西加茂郡藤岡村に露出する花崗岩より分離 *2. " " " 赤津村 " 花崗閃緑岩 "

\section{4. 結言}

ジルコン中の鉛の分光分析による定量法として内標準 そインジウムを用い， $1000 \mathrm{ppm} \mathrm{Pb}$ までの検討を行い 比較的良好な結果を得た。ただ低濃度では試薬中に含有 される微量の鉛が問題となり，またその含有量の決定法 にもなお考慮すべき問題があると考えられる，さらに鉱 物としてのジルコンの分析で最も関心を払わねばならぬ
*3. 愛知県 西加茂郡藤岡村, 藤井鉱業所の廃砂より分離 のは選鉱であり，極く少量のチタン鉄鉱，鋭錐石等が混 入しても鉛の定量值を大きくするので，乙れについては さらに厳密な方法をとり再検討したい.

最後に本実験について御協力を得た名古屋工業大学福 尾券一助教授並びに御懇篤なる御指導をいただいた名古 屋大学山崎一雄教授に対し深甚なる謝意を表する次第で ある。 